\title{
Etika Guru dalam Perspektif al-Timidzi (Studi Atas Kitab Sunan al-Tirmidzi Karya Abu Isa Muhammad Bin Isa al- Tirmidzi)
}

\author{
Ahmad Junaedy Abu Huraerah \\ Pondok Pesantren Assalam, Manado, Sulawesi Utara, Indonesia \\ Email:wahabon@gmail.com
}

\begin{abstract}
This paper is a hadith study on the concept of teachers' ethics according to Abu Isa al-Tirmidzi in his Sunan book. This concept is very relevant to the profesionalism of the Islamic religious education teachers, as stated by the Law No. 14 of 2005 on Teachers and Lecturers. In Islamic education, teachers have important meaning and roles, because not only that they have a responsibility, and determine the direction of education, they are also central in shaping individual Muslims to be in line with the educational goals of Islam. Therefore, Islam highly appreciates and respects the people who are knowledgeable and working as educators. Islam elevates and glorifies them more than other Muslims who have no knowledge and not educators. In order to obtain that award and honor, they, in the process of teaching, should observe good ethics. A teacher must possess honesty, humility, transparency in the teaching of science, and has no favoritism.
\end{abstract}

Keywords: Teachers' ethics, al-Tirmidzi, Islamic education

ABSTRAK Tulisan ini mengangkat suatu kajian hadis tentang konsep etika guru yang ditawarkan oleh Abu Isa al-Tirmidzi dalam kitab Sunannya, dan konsep ini sangat relevan terhadap profesionalitas guru Pendidikan Agama Islam, yaitu dalam Undangundang No.14 Tahun 2005 tentang Guru dan Dosen. Dalam pendidikan Islam, guru memiliki arti dan peranan sangat penting, karena selain ia memiliki tanggung jawab dan menentukan arah pendidikan, juga sentral dalam membentuk individu muslim yang sejalan dengan tujuan pendidikan Islam itu sendiri. Karena itu, Islam sangat menghargai dan menghormati orang-orang yang berilmu pengetahuan dan bertugas sebagai pendidik. Islam mengangkat derajat mereka dan memuliakan mereka melebihi dari orang Islam lainnya yang tidak berilmu pengetahuan dan bukan pendidik. Dan untuk meraih penghargaan dan kemuliaan tersebut, maka dalam proses mengajar dibutuhkan etika yang baik, yaitu seorang guru harus memiliki sifat keikhlasan, rendah diri, transparansi dalam mengajarkan ilmunya dan tidak pilih kasih.

Kata Kunci: Etika guru, al-Tirmidzi, pendidikan Islam

\section{Pendahuluan}

Dalam pendidikan Islam, guru memiliki arti dan peranan sangat penting. Hal ini disebabkan karena ia memiliki tanggung jawab dan menentukan arah pendidikan. Itulah sebabnya Islam sangat menghargai dan menghormati orang-orang yang berilmu pengetahuan dan bertugas sebagai pendidik. Islam mengangkat derajat mereka dan memulia- 
kan mereka melebihi dari orang Islam lainnya yang tidak berilmu pengetahuan dan bukan pendidik (Sudiyono, 2009).

Sehingga, sudah semestinya dan menjadi suatu kewajiban bagi seorang guru untuk mengajarkan dan mengamalkan apa yang sudah diketahui dan dipelajari. Jika kewajiban ini dikerjakan, maka perbuatan mendidik dan mengajar tersebut merupakan amal kebajikan jariyah yang akan terus-menerus mengalir pahalanya selama ilmu yang diajarkan tersebut masih diamalkan orang belajar tersebut (Nafis, 2011).

Bahkan dalam Islam penghargaan yang sangat tinggi diberikan kepada guru. Begitu tingginya penghargaan tersebut sehingga menempatkan kedudukan guru setingkat dibawah nabi dan rasul dan diibaratkan bulan purnama di tengah-tengah bintang. Semua sanjungan, kehormatan dan derajat kemuliaan tersebut adalah untuk para guru yang memiliki ilmu dan menghiasi diri mereka dengan etika terpuji. Oleh karena itu etika (akhlaq) dalam tradisi intelektual Islam, di tempatkan pada posisi yang sangat tinggi, sehingga tidak jarang ditemukan pernyataan yang menggandengkan ilmu dan etika seolah-olah dua sisi dari sebuah koin (Echsanudin, 2011). Kedudukan etika dalam kehidupan manusia menempati tempat yang penting sekali, baik secara individu maupun sebagai anggota masyarakat dan bangsa, sebab jatuh bangunnya suatu masyarakat tergantung kepada bagaimana etikanya. Apabila etikanya rusak, rusaklah lahir dan batinnya (Abdullah, 2006).

Maka etika adalah faktor terpenting yang harus dimiliki oleh seorang guru. Etika itulah yang akan menentukan apakah ia menjadi pendidik dan pembina yang baik bagi anak didiknya, ataukah akan menjadi perusak atau penghancur bagi masa depan anak didiknya. Maka keteladanan dari seorang guru menjadi harga mati yang tidak bisa ditawar-tawar. Menurut Awwad, posisi pendidik (guru) memiliki peran yang sangat penting. Sebab karakter siswa dapat terbentuk setelah melihat secara langsung perilaku gurunya (Awwad, 1996).

Olehnya itu menyandang profesi guru, berarti harus menjaga citra, wibawa, keteladanan, integritas, dan kredibilitasnya. Ia tidak hanya membimbing, menuntun, dan membentuk karakter moral yang baik bagi siswa-siswanya (Jamil, 2013). Namun kenyataannya pada masa sekarang masih banyak guru yang belum menghayati peran dan tugas mereka sebagai pendidik, terbukti dalam dunia pendidikan sekarang ini banyak media massa baik cetak maupun elektronik yang memuat kasus tindakan asusila yang dilakukan oknum guru, seperti guru memukuli peserta didiknya, guru melakukan pelecehan seksual, guru yang terlibat penipuan, pembunuhan dan kasus-kasus lainnya yang tidak pantas dilakukan oleh seorang guru (Mulyasa, 2008b).

Sejumlah fakta di atas menunjukkan bahwa kepribadian guru masih menjadi permasalahan dalam pendidikan kita, guru yang seharusnya menampilkan kepribadian yang layak, justru melakukan tindakan yang melangkahi kepribadian yang harus dimilikinya, kekerasan, ketidakjujuran, dan tindakan amoral lainnya yang dilakukan oleh guru merupakan permasalahan kepribadian yang perlu diperbaiki.

Berangkat dari fenomena tersebut di atas, Maka keteladanan dari seorang guru menjadi harga mati yang tidak bisa ditawar-tawar. Keteladanan bagaikan anak panah yang langsung mengenai sasaran. Keteladanan menjadi senjata ampuh yang tidak bisa dilawan dengan kebohongan, rekayasa, dan tipu daya. Sesungguhnya keteladanan guru memang memberikan pengaruh yang lebih besar daripada sekadar omelan atau nasihat.

Masalah etika guru juga menjadi sorotan tajam di kalangan ulama dari masa ke masa. Sehingga banyak di antara mereka seperti al-Ghazali, al-Mawardi, al-Zarnuji (Rahmadi, 2001), Ibnu Khaldun (Nizar, 2005) dan ulama lainnya yang telah berusaha 
menyusun beberapa konsep etika yang harus dimiliki oleh guru dan memposisikan guru begitu terhormat sebagai orang yang 'alim, wara' dan sebagai uswah sehingga guru dituntut juga beramal saleh sebagai aktualisasi dari keilmuan yang dimilikinya. Termasuk para ulama hadis yang mempunyai perhatian besar terhadap etika guru, seperti al-Imam al-Hāfizh Abu 'Isa Muhammad bin 'Isa bin Saurah bin Musa bin alDhahak al-Sulami al-Dhariri al-Bughi al-Tirmidzi. atau lebih dikenal dengan sebutan Imam al-Tirmidzi yang termaktub dalam kitabnya Sunan al-Tirmidzi.

Imam al-Tirmidzi dalam kitabnya Sunan al-Tirmidzi, memaparkan kedudukan dan penghargaan yang disandang oleh seorang guru, yaitu mereka mendapat julukan sebagai al-'Ulamaa Waratsat al-Anbiyaa (pewaris para nabi), dimudahkan jalannya ke surga, dimohonkan pengampunan dari makhluk-Nya, mendapatkan limpahan pahala, dimuliakan dari ahli ibadah yang tidak berilmu serta dibebaskan dari kutukan Allah Swt.,.

Kedudukan seorang guru yang dipaparkan oleh Imam al-Tirmidzi tersebut, mencerminkan betapa agung, mulia, dan terhormatnya profesi seorang guru. Dan untuk mencapai kedudukan tersebut seorang guru harus memiliki etika sebagaimana yang disebutkan oleh Imam al-Tirmidzi, yaitu ikhlas dalam mengajarkan ilmunya, rendah diri, transparan dalam menyampaikan ilmunya, dan tidak pilih kasih di antara anak didiknya. Oleh karena itu, penulis memfokuskan penelitian ini tentang konsep etika seorang guru dalam kajian hadis-hadis nabawi yang ditawarkan oleh Imam al-Tirmidzi dalam kitab Sunannya, dan direlevansikan konsep tersebut ke dalam Undang-undang No. 14 Tahun 2005 tentang Guru dan Dosen agar sejalan dengan profesionalitas guru Pendidikan Agama Islam.

\section{Imam al-Tirmidzi dan Kitab Sunannya}

Nama lengkapnya adalah Abu Isa Muhammad bin Isa bin Saurah bin Musa bin alDhahak al-Sulami al-Dhariri al-Bughi al-Tirmidzi (Al-Mubarakfury, 1990). Nisbah yang melekat dalam nama al-Tirmidzi, al-Sulami yaitu dinisbahkan kepada Bani Sulaim yang berasal dari Sulaim bin Manshur. Bani Sulaym satu kabila Qays 'Aylan (AlTabba', 2001). Sedangkan al-Bughi dinisbahkan kepada Bugh, yaitu satu salah satu desa yang terletak di Turmudz. Abu Isa dinasabkan kepada kampung ini karena beliau wafat dikampung tersebut (Turmudz), yaitu sebuah kota di tepi sungai Jihun (Amudariyah) di Khurasan bagian utara Iran. kemudian beliau lebih di kenal dengan sebutan al-Tirmidzi (Al-Mubarakfury, 1990). Kemudian sebutan al-Dariri karena ia mengalami kebutaan di masa tuanya dan belum ditemukan sumber secara pasti, apakah ia benar berasal dari Arab atau tidak. Karena sebagian dari penulis kontemporer mengatakan bahwa seluruh pengarang al-Kutub al-Sittah adalah a'jami (bukan berasal dari Arab) (Hamid, 1999).

Beliau dilahirkan di kota Tirmidz pada bulan Dzullhijjah tahun 200 H/ 815 M, dan wafat pada bulan Rajab tanggal 13 tahun 279 H pada malam Senin. Pada saat itu beliau berumur 70 tahun (Abu Salim, 2006).

Imam al-Tirmidzi menjadi buta akibat seringnya menangis, dan dia menjalani hidup dengan kebutaan mata selama beberapa tahun" (A. A. S. al-D. M. bin A. Al-Dzahabi, 1998, p. 154). Imam al-Tirmidzi adalah seorang yang zuhud dan wara'. Di samping itu, ia juga seorang individu yang sugestible, mudah hanyut perasaannya ketika tiap kali menyaksikan derita orang lain dan sering menangis ketika melihat keadaan orang lain tersebut (Al-Khatib, 1989).

Adapun sanjungan para ulama terhadap Imam a-Tirmidzi, di antaranya Umar bin Malik berkata, "Setelah Imam al-Bukhari meninggal, maka tidak ada orang di Khurazan 
yang seperti Imam al-Tirmidzi dalam keilmuan, derajat kehafizhan, kewara'an, dan kezuhudan" (A. A. S. al-D. M. bin A. Al-Dzahabi, 1998) Ibnu Hibban mengatakan bahwa Imam al-Tirmidzi adalah orang yang mengumpulkan, berkarya, mempelajari dan menghafal hadis (Al-Darimi, 1973). Al-Dzahabi berkata; bahwa karya Imam alTirmidzi merupakan bukti bahwa dia adalah seorang imam yang hafizh dan ahli fiqh. Hanya saja, kriterianya dalam meriwayatkan hadis dalam kitabnya lunak dan tidak mutasyaddid (ketat) (S. al-D. Al-Dzahabi, 1985). Al-Mizzi berkata, "Abu Isa alTirmidzi seorang ulama yang telah menelurkan karya al-Jami' dan yang lain. Dia seorang Imam terkemuka dengan predikat al-Hafizh dalam bidang hadis yang keberadaan dari dan karyanya, atas izin Allah, bermanfaat bagi kaum muslimin" (AlMizzi, 1980, p. 250).

Dalam rihlahnya, Imam al-Tirmidzi melakukan perjalanan ke berbagai negeri di antaranya Bukhara, Khurasan, Naysabur, Iraq, Hijaz, Makkah, dan beberapa negeri lainnya (Abu Salim, 2006). Akan tetapi beliau tidak melakukan perjalanan ke Mesir dan Syam (S. al-D. Al-Dzahabi, 1985). Hal ini disebabkan, karena keadaan yang tidak memungkinkan pada waktu itu, sehingga ia meriwayatkan hadis dari ulama kedua negeri ini dengan perantaraan ulama lainnya (Sutarmadi, 1998). Dalam lawatannya, Imam al-Tirmidzi selalu mencatat hadis dari ulama yang ditemuinya.

Imam al-Tirmidzi termasuk orang yang paling banyak berguru dengan para ulamaulama terkemuka pada zamannya, sebab beliau hidup di era di mana terjadi puncak perkembangan ilmu hadis. Ia belajar dan meriwayatkan hadis dari ulama-ulama kenamaan. Di antaranya adalah Imam Bukhari, Imam Muslim, al-Nasa'i, Ibnu Majah, Abu Dawud dan ulama lainnya. Sedangkan orang-orang yang meriwayatkan hadis dari beliau seperti Abu Bakar Ahmad bin Ismail al-Samarqandi, Abu Hamid Ahamd bin Abdillah bin Dawud al-Marwazi, dan lainnya.

Sebagai pecinta hadis, Imam al-Tirmidzi mencurahkan seluruh hidupnya untuk menghimpun dan meneliti hadis. Kualitas ilmunya juga tercermin dari banyaknya karya yang dihasilkannya terutama di bidang hadis yang dikukuhkan dengan sejumlah karya yang menghimpun dan mengupas tentang pribadi Rasulullah Saw.. dari berbagai sisi. Di antara karya tersebut adalah kitab Jâmi' al-Tirmidzi atau Sunan al-Tirmidzi merupakan hasil karyanya yang sangat terkenal, sehingga ia dikenal dengan Shahih al-Tasnîf. Dan kitab ini selesai disusun dan ditulis pada tanggal 10 Dzulhijjah 270 H (Azami, 1996). Ini merupakan karyanya yang terkenal dan termasuk salah satu dari al-Kutub al-Sittah dan ensiklopedia hadis terkenal.

Pujian terhadap kitab ini tidak hanya berkaitan dengan sistem penulisannya saja, akan tetapi juga penjelasan-penjelasan yang terdapat di dalam kitab tersebut. Oleh karenanya Ajjaj al-Khatib menjadikannya sebagai salah satu kitab hadis yang memenuhi standar penulisan kitab ilmiah. Alasan penilaian tersebut didasarkan kepada adanya pembahasan yang tuntas berkaitan dengan tema-tema yang termasuk dalam kategori ilmu hadis, misalnya berkaitan dengan istilah hasan, daif serta penjelasan tentang 'illat (cacat) hadis yang terdapat dalam kitab tersebut. Terkadang juga ditemukan penjelasan istinbath dari hadis-hadis tersebut di atas, hal itu jarang ditemukan di dalam kitab-kitab hadis lainnya (Al-Khatib, 1989). Oleh karena itu, kitab ini mudah untuk dipelajari jika dibandingkan dengan kitab hadis lainnya.

Metode yang dipergunakan oleh Imam al-Tirmidzi dalam menyusun kitab Sunannya adalah dengan mencantumkan judul pada setiap bab, kemudian mencantumkan satu atau dua hadis yang dapat mencerminkan dan mencakup isi judulnya. Setelah itu, alTirmidzi mengemukakan opini pribadi tentang kualitas hadis tersebut apakah sahih, 
hasan atau da if. Untuk tujuan ini al-Tirmidzi menggunakan istilah yang tidak biasa dipakai oleh para ulama sebelumnya.

Al-Tirmidzi juga seringkali mencantumkan opini-opini yurisprudensi para ahli hukum terdahulu, para Imam mazhab yang berkaitan dengan berbagai macam masalah hukum Islam (fiqh). Lebih dari pada itu al-Tirmidzi juga menunjukkan jika masih ada beberapa hadis yang diriwayatkan oleh para sahabat lainnya yang berkenaan dengan masalah yang sama.

Sementara itu dalam meriwayatkan hadis, al-Tirmidzi menggunakan metode yang berbeda dengan para ulama hadis lainnya, metode-metode tersebut adalah men-takhrij hadis yang menjadi amalan ( $m a^{\prime} m u l$ ) oleh para fuqaha dan memberikan penjelasan terhadap kualitas dan keadaan hadis yang ditulis. Dengan melihat metode yang digunakan oleh al-Tirmidzi, maka dapatlah dipahami bahwa usaha menjelaskan keadaan suatu hadis dimaksudkan oleh al-Tirmidzi untuk mengetahui kelemahan hadis yang bersangkutan.

Imam al-Tirmidzi dalam menyusun kitab Sunan tidak hanya meriwayatkan hadis sahih saja, namun juga beserta hadis yang hasan, dha'if, gharib dan mu'allal. akan tetapi Imam al-Tirmidzi menjelaskan sebab lemahnya hadis tersebut. Beliau memasukkan hampir 50 kitab dan hadisnya berjumlah 3956 hadis (Blog Ahlulhadist, 2007).

\section{Konsep Etika Guru Dalam Islam}

Etika sering disamakan dengan pengertian akhlak dan moral. Secara etimologis kata etika berasal dari bahasa Yunani kuno yaitu ethos (jamak: ta etha) yang berarti watak kesusilaan atau adat kebiasaan (Masyhur, 1994). Pendapat lain mengatakan, etika berasal dari bahasa latin yakni ethicus yang berarti kesusilaan atau moral. Maksudnya tingkah laku yang berkaitan dengan norma-norma sosial baik yang sedang terjadi atau yang akan terjadi (Supriyadi, 2010). Kata etika ( $a d a b$, plural $\bar{a} d \bar{a} b$ ) dalam kamus bahasa Arab berasal dari kata: أَدُبَ يَادُدْبُ أَدَبًا artinya: beradab, bersopan santun, sedangkan kata

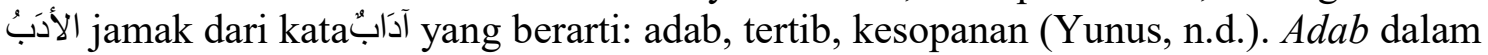
kehidupan sehari-hari sering diartikan tata karma, sopan santun, akhlak, budi pekerti (Munawwir, 2007).

Sedangkan secara terminologis etika berarti pengetahuan yang membahas baikburuk atau benar-tidaknya tingkah laku dan tindakan manusia serta sekaligus menyoroti kewajiban-kewajiban manusia. Dalam bahasa gerik etika diartikan ethicos is a body of moral principles or value. Ethics arti sebenarnya adalah kebiasaan. Namun lambat laun pengertian etika berubah, seperti sekarang. Etika ialah suatu ilmu yang membicarakan masalah perbuatan atau tingkah laku manusia, mana yang dapat dinilai baik dan mana yang dapat dinilai buruk dengan memperlihatkan amal perbuatan manusia sejauh yang dapat dicerna akal pikiran (Rahmaniyah, 2010).

Adapun akhlak secara etimologi istilah yang diambil dari bahasa Arab dalam bentuk jamak. Al-Khulq merupakan bentuk mufrad (tunggal) dari akhlak yang memiliki arti kebiasaan, perangai, tabiat, budi pekerti (Yunus, n.d.). Secara etimologi kedua istilah akhlak dan etika mempunyai kesamaan makna yaitu kebiasaan dengan baik dan buruk sebagai nilai kontrol. sedangkan kata moral adalah nilai-nilai dan norma-norma yang menjadi pegangan bagi seseorang atau suatu kelompok dalam mengatur tingkah lakunya.

Jadi persamaan antara Akhlak, Etika, Moral, dan Adab adalah bahwa dalam menentukan hukum atau nilai perbuatan manusia dilihat dari baik dan buruk, sementara perbedaannya terletak pada tolak ukurnya. Akhlak menilai dari ukuran ajaran Alquran 
dan Alhadis, etika berkaca pada akal pikiran dan moral dengan ukuran adat kebiasaan yang umum di masyarakat. Maka dapat disimpulkan dari pemaparan di atas bahwa akhlak yang dimaksud adalah pengetahuan menyangkut perilaku lahir dan batin manusia.

Kata guru dalam Kamus Umum Bahasa Indonesia, berarti orang yang pekerjaannya mengajar (Poerwadarminta, 2011). Guru dalam bahasa Inggris ditemui kata teacher yang berarti guru atau pengajar, selain itu terdapat kata tutor yang berarti guru pribadi, guru yang mengajar di rumah, pemberi les, instructor yang diartikan guru, pelatih atau lektor, lecturer yang berarti dosen, pemberi kuliah, atau penceramah, trainer artinya pelatih atau penggembleng, dan educator yang diartikan pendidik atau ahli mendidik.

Dalam bahasa Arab istilah yang mengacu kepada pengertian guru, yaitu al-'Alim (jamaknya 'ulama) atau al'Mua'allim, yang berarti orang yang mengetahui dan banyak digunakan para ulama/ahli pendidikan untuk menunjuk pada hati guru. Selain itu, adalah al-Mudarris (untuk arti orang yang mengajar atau orang yang memberi pelajaran) dan al-Muaddib (yang merujuk kepada guru yang secara khusus mengajar di istana) serta $a l-U s t a d z$ (untuk menunjuk kepada guru yang mengajar bidang pengetahuan agama Islam, serta $a l-U s t a d z$ (untuk menunjuk kepada guru yang mengajar bidang pengetahuan agama Islam, dan sebutan ini hanya dipakai oleh masyarakat Indonesia dan Malaysia).

Dari uraian di atas secara sederhana dapat dipahami bahwa seseorang yang melakukan aktivitas dalam menyampaikan pengetahuan, keterampilan, pengalaman, dan sebagainya disebut guru. Penyandang predikat guru boleh diemban oleh siapa saja dan di mana saja, baik oleh guru di sekolah, oleh orang tua di rumah, maupun oleh tokoh masyarakat di lingkungan masyarakat itu sendiri. Dan lebih spesifik lagi guru adalah orang yang bertanggung jawab terhadap berlangsungnya proses pertumbuhan dan perkembangan potensi anak didik, baik potensi kognitif maupun potensi psikomotorik (Tafsir, 2010).

Dalam melaksanakan tugas profesinya guru menyadari sepenuhnya bahwa perlu ditetapkan etika guru sebagai pedoman bersikap dan berperilaku yang mengejewantah dalam bentuk nilai-nilai moral dan etika dalam jabatan guru sebagai pendidik puteraputeri bangsa. Beberapa ahli pendidikan Islam telah merumuskan etika seorang guru yang harus dipenuhi, terutama dari aspek kepribadian. Al-Ghazali menyebut beberapa sifat yang harus dipenuhi guru, yaitu : a) kasih sayang dan lemah lembut; b) tidak mengharap upah, pujian, ucapan terima kasih atau balas jasa; c) jujur dan terpercaya bagi murid-muridnya; d) membimbing dengan kasih sayang, tidak dengan marah; e) luhur budi dan toleransi; f) tidak merendahkan ilmu lain di luar spesialisasinya; g) memerhatikan perbedaan individu; dan h) konsisten (Al-Ghazali, 2005).

Ibn Khaldun (Nizar, 2005) berpendapat bahwa seorang guru harus mempunyai etika dalam proses pembelajaran. Yaitu; a) Adanya pemahaman dan pengulangan secara berproses; b) Seorang guru dalam melaksanakan tugas kependidikannya harus mengerti psikologi murid-muridnya; c) Dalam menyajikan materi pelajaran, hendaknya guru memfokuskan pada satu masalah, jangan mencampuradukan; d) Dalam menyajikan materi pelajaran, hendaknya seorang guru jangan terlalu lama mengulur waktu sehingga menganggu jadwal belajar seharusnya; e) Utamakan pemahaman pelajaran, jangan hanya hafalan; f) Seorang guru hendaknya bersikap kasih sayang terhadap anak didiknya (Suyitno, 2006).

Abd al-Rahman al-Nahlawi (2007) menyebutkan beberapa sifat yang harus dimiliki oleh para guru, yaitu a) Seorang guru harus memiliki sifat rabbani; b) Seorang guru 
harus memiliki keikhlasan; c) Seorang guru harus melaksanakan tugas kependidikannya dengan sabar; d) Jujur; e) Selalu berusaha meningkatkan ilmu dan terus mengkajiinya; f) Mengusai berbagai metode mengajar dan mampu memilih metode yang sesuai; g) Mampu mengelola murid, tegas dalam bertindak serta meletakkan berbagai perkara secara proporsional; h) Bersikap adil dalam menghadapi murid.

Menurut Asma Hasan Fahmi (1979), sifat-sifat yang harus dimiliki pendidik adalah a) tidak boleh mengharapkan upah dan imbalan materi dari pekerjaan mengajar, karena tujuan mengajar tidak lain untuk mengharap ridla Allah; b) guru harus lebih dahulu membersihkan anggota badan dari dosa-dosa; c) harus sesuai antara perkataan dan perbuatan; d) rendah hati dan tidak perlu malu dengan ucapan "tidak tahu"; e) harus pandai menyembunyikan kemarahan, dan menampakkan kesabaran, hormat, lemah lembut, kasih sayang dan tabah unuk mencapai sesuatu keinginan.

Sedangkan Abdullah Nashih Ulwan dalam bukunya Tarbiyah al-Aulad fi al-Islami menyatakan bahwa seorang guru hendaknya memiliki lima karakter dasar, yaitu: keikhlasan, ketakwaan, ilmu, kesabaran, dan menyadari tanggung jawabnya ('Ulwan, 2008).

Sifat-sifat guru sebagaimana disebutkan oleh beberapa tokoh di atas, sangat ideal, tapi masih bisa dilakukan asal ada kemauan keras dari para guru. Di era sekarang, ketika ukuran-ukuran moral kian terpinggirkan oleh pola hidup modern yang sekuler, sifatsifat ideal tersebut semakin terasa untuk direaktualisasikan. Yang menarik dari beberapa pendapat di atas, al-Ghazali dan Hasan Fahmi sama-sama mempersyaratkan agar guru tidak menerima gaji. Bagaimana jika hal ini dihubungkan dengan konteks sekarang?. Menurut al-Qabisi, kondisi guru perlu dibedakan antara periode awal Islam dengan masa sesudahnya. Di masa awal, tugas mengajarkan agama dilakukan secara sukarela ditopang semangat dakwah yang tinggi dan tanpa gaji. Tapi, setelah Islam menyebar luas, semakin sulit mendapatkan orang yang mau mengajar umat Islam dan anak-anak mereka, karena pekerjaan mengajar memerlukan ketekunan dan harus meninggalkan kegiatan usaha untuk memenuhi kebutuhan hidupnya. Untuk itu, kata al-Qabisi, umat Islam selayaknya memberikan gaji kepada orang lain yang mau membaktikan dirinya untuk mengajar anak-anak mereka secara rutin (Al-Tuwanisi, 1994).

Apa yang disampaikan para ahli pendidikan Islam di atas adalah karakteristik guru secara umum. Sedangkan bagi guru profesional, ada beberapa kreteria tambahan yang harus dipenuhi. Untuk kasus Indonesia, misalnya, ketentuan tentang guru profesional diatur dalam Undang-undang No.14 tahun 2005 tentang Guru dan Dosen. Pada pasal 1 ayat (1) dinyatakan, guru adalah:

"Pendidik profesional dengan tugas utama mendidik, mengajar, membimbing, mengarahkan, melatih, menilai, dan mengevaluasi peserta didik pada pendidikan anak usia dini jalur pendidikan formal, pendidikan dasar, dan pendidikan menengah.”

\section{Etika Guru Dalam Perspektif Imam al-Tirmidzi}

Guru adalah profesi yang mulia, tidak dapat disamai oleh profesi lain apa pun dalam hal keutamaan dan kedudukan. Semakin bermanfaat materi ilmunya maka semakin tinggi pula kemuliaan dan derajat pemiliknya. Dan ilmu yang paling mulia secara mutlak adalah ilmu syari'at, baru kemudian ilmu-ilmu pengetahuan yang lain, masing-masing sesuai dengan tingkatannya. Tugas seorang guru tidak sebatas menyampaikan materi pelajaran kepada anak didik saja bahkan ia merupakan tugas yang berat dan sulit, tetapi akan mudah bagi siapa yang dimudahkan Allah Swt. Tugas tersebut menuntut seorang pengajar bersifat sabar, amanah, ketulusan, dan mengayomi 
yang di bawahnya. Beberapa etika yang harus dimiliki oleh seorang guru, sebagaimana yang di paparkan oleh Imam al-Tirmidzi dalam beberapa riwayatnya yaitu:

\subsection{Ikhlas dalam Mengajarkan Ilmunya}

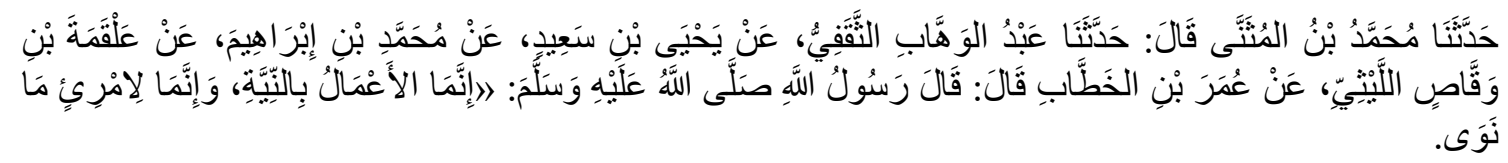

Terjemahan:

"Imam al-Tirmidzi meriwayatkan bahwa telah menceritakan kepada kami Muhammad bin al-Mutsanna berkata: telah menceritakan kepada kami Abd alWahhab al-Tsaqafy, dari Yahya bin Sa'id dari Muhammad bin Ibrahim, dari Alqamah bin Waqqash al-Laitsy, dari Umar bin al-Khattab berkata: Rasulullah Saw.. bersabda: "Semua perbuatan tergantung niatnya, dan (balasan) bagi tiaptiap orang (tergantung) apa yang diniatkan."

Riwayat al-Tirmidzi ini menunjukkan bahwa niat merupakan timbangan penentu kesahihan amal. Apabila niatnya baik, maka amal menjadi baik. Apabila niatnya jelek, amalnya pun menjadi jelek. Dan ini merupakan perkara yang agung yang banyak dilalaikan oleh kalangan guru dan pendidik, yaitu membangun dan menanamkan prinsip mengikhlaskan ilmu dan amal hanya untuk Allah. Berapa banyak ilmu yang bermanfaat dan amalan-amalan yang mulia untuk umat, namun pemiliknya tidak mendapat bagian manfaat darinya sedikitpun dan hilang begitu saja bersama hembusan angin bagaikan debu yang beterbangan. Demikian itu disebabkan karena sosok guru yang tidak mengikhlaskan ilmu dan amal mereka serta tidak menjadikannya di jalan Allah. Tujuan mereka bukan untuk memberikan manfaat kepada anak didiknya dengan ilmu dan pengetahuan serta amalan-amalan tersebut. Tujuan mereka hanya semata meraih kehormatan atau kedudukan dan sejenisnya, karena itu sangat layak bila amalan-amalan tersebut hilang begitu saja bagaikan debu yang beterbangan. Ya, benar adakalanya mereka itu mendapatkan manfaat dengan ilmu dan pengetahuan mereka di dunia, berupa sanjungan, pujian, dan sejenisnya, tetapi ujung-ujungnya bermuara kepada kesirnaan.

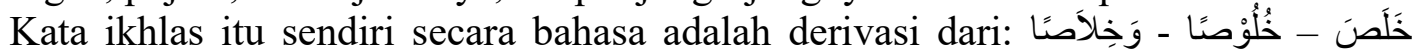
yang artinya murni, tiada bercampur, bersih, jernih (Munawir \& Al-Bisri, 1999). Berkaitan dengan ikhlas, Nawawi mengungkapkan bahwa:

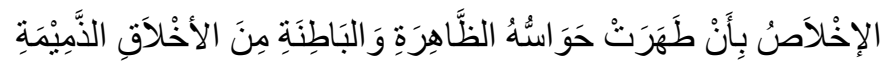

"Ikhlas yaitu membersihkan panca indranya dengan lahir dan batin dari budi pekerti yang tercela." (Al-Bantani, $1439 \mathrm{H}$ ).

Arberry dalam bukunya Sufism: An Account of the Mystics of Islam, mengatakan ikhlas (sincerity) that is, seeking only God in every act of obedience to Him (Arberry, 1996, p. 77). Ikhlas atau ketulusan hati yaitu, yang dalam setiap perbutannya ditujukan hanya semata-mata karena Tuhan. Pentingnya sifat ikhlas ini, digambarkan juga oleh Ibnu al-Qayyim sebagai ruh (nyawa) dalam perbuatan, ikhlas adalah pemandu bagi perbuatan, menjadi pondasinya, dan orang yang melakukan suatu perbuatan yang tidak didasari dengan niat ikhlas, maka akan mendapatkan kehinaan (Al-Jawziyyah, 1423). Adapun pandangan ulama taSawuf mengenai ikhlas, sebagaimana yang dikutip oleh alGhazali dalam kitabnya Ihya Ulum al-Din, di antaranya; al-Junaid (Faturahman, 2012) 
berpandangan bahwa, ikhlas adalah membersihkan perbuatan dari kotoran (Al-Ghazali, 2005).

Beberapa pengertian di atas, maka dapat disimpulkan bahwa ikhlas adalah mengerjakan suatu amal perbuatan semata-mata hanya untuk mendapatkan rida dari Allah Swt. bukan untuk meraih pamrih duniawi, dengan tidak mengharapkan pujian dari manusia dan senantiasa menjaga niatnya dengan benar.Oleh karena itu, menjadi sangat penting diperhatikan bagi siapa saja yang bergelut dalam dunia keilmuan, baik para petualang ilmu maupun orang-orang yang mengajarkan ilmu (guru), agar mereka memiliki keikhlasan dalam dirinya.

Lalu bagaimana guru yang mengharapkan upah dari kegiatan mengajar? Apakah mereka jauh dari nilai-nilai ikhlas?

Khalid bin Utsman al-Sabt, menulis dalam A'mal al-Qulüb-nya tentang ikhlas, bahwa ikhlas memiliki dua tingkatan, Pertama, ikhlas yang semata-mata ditujukan hanya kepada Allah, sama sekali pelakunya tidak mengharapkan balasan duniawi. Kedua, ikhlas yang tetap ditujukan kepada Allah, namun ia berharap akan balasan duniawi. Bagian yang kedua ini, tetap dikategorikan sebagai perbuatan ikhlas, walaupun jelas tingkatannya dibawah bagian yang pertama (Al-Sabt, 2016).

Dengan demikian, guru yang melakukan tugas sembari mengharapkan upah dengan tetap menjadikan tujuan awal karena-Nya, maka ia masih bisa dibenarkan sebagai amalan ikhlas kategori jenis kedua. Pendapat ini, sangat relevan dengan dunia pendidikan sekarang. Di mana guru zaman sekarang mendapatkan gaji dari ia mengajar yang memang itu hak mereka sebagai pengganti akan waktu yang mereka curahkan untuk mengajar sehingga tidak sempat lagi untuk mencari nafkah.

Guru tetap dinilai ikhlas yakni bertujuan menyebarkan ilmu dan mendapat pahala akhirat karena gaji yang diambil dimaksudkan sebagai sarana untuk menunjang tugasnya mentransfer ilmu. Sebaliknya, jika kesibukan guru mengajar atau mentransfer ilmu bertujuan untuk mendapatkan harta, berarti guru telah menjadikan profesinya dalam mentransfer ilmu sebagai sarana untuk memperoleh harta (Rahmadi, 2001). Untuk medukung tugas, kedudukan dan juga keprofesionalan guru, maka guru berhak menerima kesejahteraan (Tafsir, 2010), dalam arti bukan meminta ataupun menuntut hak, tetapi bagaimana meningkatkan kesadaran masyarakat untuk menghargai jasa guru.

Maka dapat dipahami bahwa belajar mengajar adalah kewajiban, kewajiban itu harus ditunaikan, kewajiban mengajar bagi guru tidak akan terlaksana tanpa adanya dukungan yaitu kesejahteraan dan juga peningkatan kualitas. Akibatnya proses transfer of knowledge akan mengalami kemandegan. Oleh karena itu, peningkatan sumber daya manusia dan juga kesejahteraan wajib adanya. Kewajiban itu diperuntukkan bukan dari guru meminta, tetapi kesejahteraan itu disediakan dan dijamin untuk guru agar senantiasa mendukung keikhlasan, kerajinan dan keprofesionalan guru (Unger, 2013).

\subsection{Bersifat Tawādhu' (Rendah Hati)}

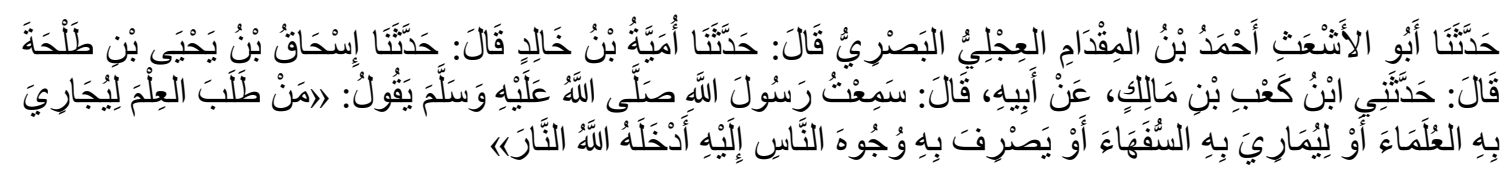

Terjemahan:

"Imam al-Tirmidzi meriwayatkan bahwa telah menceritakan kepada kami Abu alAsy'ats Ahmad bin al-Miqdam al-'Ijli al-Bashri, telah menceritakan kepada kami 
Umayyah bin Khalid, telah menceritakan kepada kami Ishaq bin Yahya bin Thalhah telah bercerita kepada kami Ibnu Ka'ab bin Malik dari bapaknya dia berkata: Aku mendengar Rasulullah Saw. bersabda: "Barangsiapa menuntut ilmu untuk mendebat para ulama, atau untuk mengolok-olok orang bodoh atau untuk mengalihkan pandang-an manusia kepadanya, niscaya Allah akan memasukkannya ke dalam neraka."

Riwayat al-Tirmidzi ini tampak jelas bahwa larangan berbuat congkak terlebih bagi seorang pendidik, alangkah naifnya jika seorang yang seharusnya jadi panutan dan memiliki integritas moral yang tinggi malah melakukan perbuatan yang dibenci banyak orang. Memilki ilmu bukanlah untuk kesombongan, meremehkan orang, menganggap dialah yang paling mengerti, sehingga orang lain dianggap kecil, bahkan kepada gurugurunya dan senior-seniornya ia tidak segan-segan untuk mendebat mereka dan menjatuhkannya dengan kata-kata yang diucapkan. Sikap-sikap seperti ini jelas sangat bertentangan dengan nilai-nilai tawadlu' (rendah hati).

Pengertian tawā Dan ini tidak akan mendongkrak pelakunya menjadi terpuji melainkan bila dibarengi karena mengharap wajah Allah Swt. (Al-Syaqawi, 2013) Ibnu Hajar mendefenisikan tawādhu' adalah menampakkan diri lebih rendah pada orang yang ingin mengagungkannya. Ada pula yang mengatakan bahwa tawạ̈̂hu' adalah memuliakan orang yang lebih mulia darinya (Al-Asqalany, n.d.).

Syeikh al-Islam Ibnu Taimiyah mengatakan, kalau sekiranya ada orang bersikap tawāẹhu' agar Allah Swt. mengangkat derajatnya dimata orang, maka ini belum dikatakan telah merengkuh sifat tawā didasari agar mulia dimata orang, dan sikap seperti itu menghapus tawā sebenarnya (T. al-D. A. bin A. al-H. bin Taimiyah, 1987). Ucapan beliau didasari sebuah hadis yang dikeluarkan oleh Imam Muslim dari sahabat Abu Hurairah ra. bahwa Nabi Saw., bersabda:

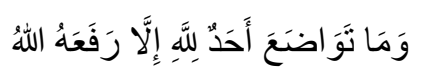

Terjemahan:

"Tidaklah seseorang merendahkan diri karena Allah melainkan (pasti) Allah akan mengangkat derajatnya."

Maksud hadis tersebut, bahwa Allah Swt. akan meninggikan derajatnya di dunia maupun di akhirat. Di dunia, orang akan menganggapnya mulia, Allah pun akan memuliakan dirinya di tengah-tengah manusia, dan kedudukannya akhirnya semakin mulia. Sedangkan di akhirat, Allah akan memberinya pahala dan meninggikan derajatnya karena sifat tawạ̄̂hu'nya di dunia (Al-Nawawi, 1998). Bahkan menurut Ibnu Taimiyah orang yang berbuat tawadlu' maka Allah akan menjadikan hamba-hambaNya berbuat tawā dhu' kepadaNya. Sebaliknya orang-orang yang merendahkan hambahambaNya, maka ia akan direndahkan oleh Allah Swt. lewat hamba- hamba-Nya yang lain (I. Taimiyah, n.d.). Imam al-Syafi'i berkata, "Orang yang paling tinggi kedudukannya adalah orang yang tidak pernah menampakkan kedudukannya. Dan orang yang paling mulia adalah orang yang tidak pernah menampakkan kemuliannya" (Al-Baihaqi, 2003, p. 515).

Paparan singkat tentang keutamaan sifat tawā harus memiliki sifat tersebut, karena seorang guru memegang peranan amat penting, bahkan berada pada garda terdepan dalam proses pendidikan. Keberhasilan pendidikan 
sebagian besar tergantung kepada kualitas guru baik dari penguasaannya terhadap materi pelajaran yang diajarkan maupun cara menyampaikan pelajaran tersebut secara etikanya yang baik, yaitu pribadi yang terpadu antara ucapan dan perbuatannya secara harmonis.

E. Mulyasa pernah mengingatkan guru yang bersikap paling pandai sehingga merasa besar kepala, bahwa perasaan paling pandai bagi guru ini menyesatkan, karena dalam kondisi seperti sekarang ini murid bisa belajar melalui internet dan berbagai media massa, yang mungkin guru belum menikmatinya. Dengan demikian dalam hal tertentu, mungkin saja murid yang belajar lebih pandai dari pada guru yang mengajar. Jika ini benar terjadi, maka guru harus bersedia belajar kembali, bahkan belajar dari murid-muridnya (Mulyasa, 2008a).

Secara singkat beberapa manfaat yang bisa dipetik dari hadis tersebut tentang sikap tawā $h$ hu' atau rendah diri, yaitu; a) Tawā mengantarkan pada surga. b) Allah Swt. akan mengangkat kedudukan orang yang rendah diri dihati manusia. Dikenang kebaikannya oleh orang lain serta diangkat derajatnya diakhirat. c) Bahwa sikap tawā beriman, adapun pengumpul dunia serta orang yang sesat maka bersikap rendah diri terhadap mereka akan menjadikan kehinaan. d) Sifat tawạ̄hu' sebagai bukti akan keindahan akhlak serta pergaulannya. e) Bahwa sifat tawāḍ h' merupakan sifatnya para Nabi dan Rasul.

\subsection{Transparan dalam Menyampaikan Ilmunya}

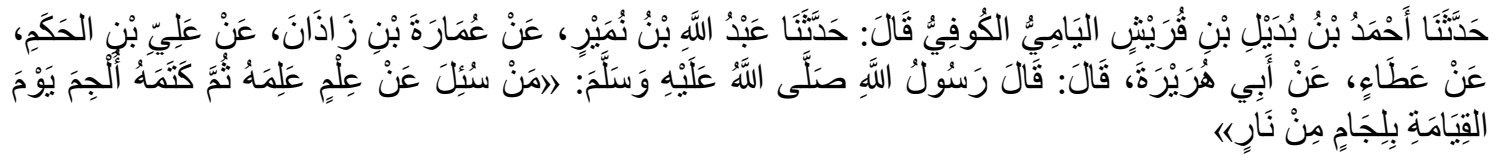

Terjemahan:

"Imam al-Tirmidzi meriwayatkan telah menceritakan kepada kami, Ahmad bin Budail bin Quraisy al-Yamiyyu al-Kufi, telah menceritakan kepada kami Abdullah bin Numair dari Umarah bin Zadzan dari Ali bin al-Hakam dari 'Atha' dari Abu Huraerah dia berkata, "bersabda Rasulullah Saw.. "Barangsiapa ditanya tentang suatu ilmu yang dia ketahui kemudian dia menyembunyikannya, maka dia akan dicambuk pada hari kiamat dengan cambukan dari neraka."

Imam al-Tirmidzi dalam riwayatnya menjelaskan bahwa bahwa ilmu bukan untuk dibangga-banggakan tapi untuk diamalkan dan disebarkan kepada orang yang belum tahu. Seorang alim (guru) akan mendapatkan siksaan yang paling keras di hari kiamat kelak bila ia menyembunyikan dan tidak mengamalkan ilmunya (Al-Math, 1995). Orang yang menyembunyikan ilmunya akan mendapat ancaman adalah ilmu yang dibutuhkan oleh penanya tentang masalah agamanya kemudian ia menyembunyikan ilmu tersebut dengan tidak memberikan jawaban, maka orang tersebut pantas dibungkam mulutnya (karena mulut alat untuk mengeluarkan ilmu dan ucapan) dengan lijam (alat untuk membungkam kuda, supaya tidak berontak) dari api neraka, sebagai balasan setimpal baginya, karena seakan-akan sebagaimana pendapat al-Thibby, ia telah membungkam dirinya dengan tidak memberikan jawaban berupa ilmu yang dibutuhkan, dan diserupakan dengan tali kendali dimulut binatang karena sama-sama diam. Orang alim diam dengan ilmunya sedangkan binatang diam terkendali tidak dapat melakukan kehendaknya secara bebas (Al-Mubarakfury, 1990). 
Menurut al-Sayyid, bahwa maksud ilmu di sini adalah ilmu wajib diajarkan seperti mengajarkan keislaman terhadap orang kafir, mengajarkan shalat pada waktunya, minta fatwa tentang halal dan haram bukan ilmu sunah yang tidak merupakan keharusan. Sedangkan Al-Munawiy berkata, hadis tersebut berisikan sanksi hukum atas sebuah dosa, karena Allah Swt. telah mengambil perjanjian terhadap kaum yang diberikan alKitab (ahli kitab) agar menerangkannya kepada manusia dan tidak menyembunyikannya. Lebih lanjut beliau mengatakan, bahwa orang yang menyembunyikan ilmu pada hakekatnya telah membatalkan hikmah ini. Ia sangat jauh dari sifat bijaksana dan mutqin (kokoh dalam ilmu). Oleh karena itu, balasan baginya adalah dikekang sebagaimana hewan kekangan yang dipaksa dan dicegah dari apa yang dikehendakinya. Sesungguhnya kedudukan seorang alim (ulama) adalah mengajak manusia kepada kebenaran dan membimbing mereka kepada jalan yang lurus" (Al-Munawi, n.d., vol. 7; 146).

Shalih Ali Syeikh menguatkan pendapat di atas bahwa, ilmu yang dimaksud mendatangkan ancaman manakala disembunyikan adalah ilmu syar' $i$, sedangkan ilmu duniawi (seperti ilmu tekhnik, kedokteran, kimia) tidak sampai pada ancaman tersebut (Syekh, 2006, vol. 2).

Maka guru dalam hal ini, harus benar-benar memerhatikan pesan dari kandungan hadis di atas, tidak hanya membayangkan ancaman masa depan di akherat kelak yang begitu mengerikan, namun ia juga harus membayangkan implikasi negatif terhadap kemunduran suatu peradaban akibat tidak adanya tranparansi dalam dunia keilmuan. Olehnya itu, etika seorang penuntut ilmu atau seorang guru hendaknya menyiarkan ilmunya yang merupakan zakat dari mereka yang memiliki ilmu pengetahuan, karena ilmu pengetahuan adalah milik Allah yang dititipkan kepada orang 'alim (guru) dan penuntut ilmu, maka hendaklah dia mengajarkannya kepada yang lain, karena Allah telah menganugerahkan ilmu pengetahuan itu kepadanya (Nada, 2005).

Adapun faidah atau manfaat yang bisa dipetik dari hadis tersebut, adalah; a) Kewajiban seorang guru atau 'alim menyampaikan ilmu kepada orang lain yang membutuhkan penjelasannya terutama anak-anak didiknya. b) Larangan menyembunyikan ilmu syara' yang dibutuhkan orang lain. c) Sifat guru yang baik adalah terbuka, transparan, dan pemurah dalam ilmu yang dibutuhkan oleh masyarakat. d) Ancaman penyimpan ilmu sejenis dengan perbuatannya, yakni diikat mulutnya dengan api neraka, karena mulutnya bungkam tidak menjawab kebenaran.

\subsection{Bersikap Adil dan Tidak Pilih Kasih}

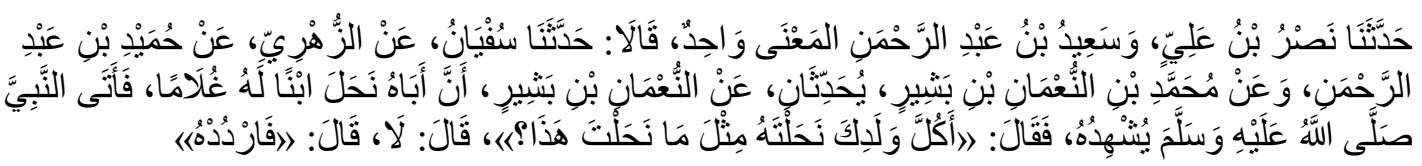

Terjemahan:

"Telah menceritakan kepada kami Nashr bin Ali dan Sa'id bin Abd al-Rahman alMakhzumi dengan satu makna, keduanya berkata; telah menceritakan kepada kami Sufyan dari al-Zuhri dari Humaid bin Abd al-Rahman dan dari Muhammad bin alNu'man bin Basyir. Keduanya menceritakan dari al-Nu'man bin Basyir bahwa ayahnya pernah memberikan seorang budak kepada anaknya. Lalu ia menemui Nabi Saw., mempersaksikan kepada beliau. Beliaupun bertanya: "Apakah engkau 
memberi seluruh anakmu?" ia menjawab; tidak. Beliau mengatakan: "Ambillah ia kembali."

Imam al-Tirmidzi meriwayatkan, bahwa Nu'man bin Basyir menceritakan kalau ayahnya pernah memberikan seorang budak kepada anaknya. Lalu, ia menemui Nabi Saw, mempersaksikan kepada beliau. Beliaupun bertanya:

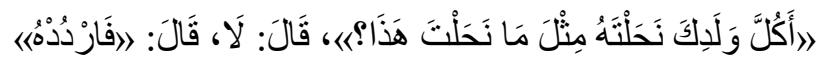

Terjemahan:

"Apakah engkau memberi seluruh anakmu?" ia menjawab; tidak. Beliau mengatakan: "Ambillah ia kembali."

Hadis ini menjelaskan tentang pengajaran Nabi Saw., terhadap seorang bapak atau guru agar bertindak seadil-adilnya terhadap anak-anaknya. Seorang bapak di dalam rumah tangganya sebagai pendidik terhadap keluarganya harus bersikap adil baik dalam sikap, ucapan, dan segala tindakan. Karena sikap adil ini mempunyai pengaruh yang besar dalam pembinaan keluarga yang bahagia dan sejahtera. Tindakan adil dari orang tua atau dari seorang pendidik merupakan pendidikan terhadap anak-anaknya (Khon, n.d.).

Ketidakadilan dan sikap pilih kasih serta bersikap diskriminasi sesama anak baik dalam masalah sepele atau besar, karena sikap demikian akan menciptakan kebencian dalam dada dan menumbuhkan benih kedengkian dan kekecewaan serta menyebabkan sifat pengecut, takut, tidak percaya diri, putus asa dalam hidup dan suka menodai hak orang serta membangkang. Bahkan akan menimbulkan berbagai macam penyakit kejiwaan, perasaan rendah diri dan dekadendi moral dan keganjilan prilaku dalam hidup. Perasaan itulah yng timbul pada diri saudara-saudara Yusuf, sebagaimana firman Allah Swt.:

"Ketika mereka berkata: "Sesungguhnya Yusuf dan saudara kandungnya (Bunyamin) lebih dicintai oleh ayah kita dari pada kita sendiri, padahal kita (ini) adalah satu golongan (yang kuat). Sesungguhnya ayah kita adalah dalam kekeliruan yang nyata" (Qs. Yusuf: 8).

Akibatnya mereka berkomplok untuk mencelakai Yusuf bahkan merencanakan untuk membunuhnya,

"Bunuhlah Yusuf atau buanglah dia kesuatu daerah (yang tak dikenal) supaya perhatian ayahmu tertumpah kepadamu saja, dan sesudah itu hendaklah kamu menjadi orang-orang yang baik.” (Qs. Yusuf: 8).

Oleh karena itulah Rasulullah Saw., telah menerangkan bagaimana cara memperlakukan anak dengan baik dan membuat mereka agar menaati orangtua atau gurunya. Yakni dengan perlakuan adil dan tidak pilih kasih kepada anak-anaknya atau anak didiknya (Suwaid, 2009).

Anak-anak diharapkan akan patuh kepada orang tua atau gurunya yang selalu adil dan tidak pilih kasih, dan orang tua atau guru lebih mudah mengatur mereka karena mereka semua merasa diperhatikan dan disayang oleh orang tuanya atau gurunya.

Berbeda dengan sikap tidak adil dan pilih kasih yang ditunjukkan oleh orangtua selalu pendidik, maka akan menimbulkan kecurigaan pada hati sebagian anak-anak terhadap orang tuanya atau gurunya yang selalu memerhatikan salah satu anak kesayangannya dan mengabaikan yang lain. Apalagi sebagai anak manusia, kadang dihinggapi rasa iri dan dengki, sehingga membuat problem rumah tangga dan sedikit kesalahan 
orang tua yang terjadi akan menjadi kesalahan yang besar di mata sang anak yang merasa dirinya tidak diperhatikan oleh orang tuanya, kemudian dampak buruknya cepat atau lambat akan dirasakan oleh orang tua itu sendiri (Abu Ibrahim Muhammad Ali, 2016).

Di antara dampak buruk pilih kasih orang tua terhadap anaknya atau seorang guru terhadap anak didiknya, anak menjadi sulit diatur, wibawa guru atau orangtua hilang di mata anak-anaknya, dan pada akhirnya guru atau orang tua tidak bisa mendidik dan menyampaikan nasehatnya kepada anaknya, dikarenakan mereka telah curiga dan berburuk sangka kepada orang tua atau gurunya.

Dampak lain yang dirtimbulkan sebagaimana yang dijleaskan oleh Syeikh Abdul Ghani al-Nablisi bahwa, akan menimbulkan permusuhan, kedengkian, dan kebencian di antara sesama anak-anak itu sendiri, kemudian akibat selanjutnya akan terjadilah pemutusan hubungan keluarga disebabkan oleh sikap pilih kasih orang tua mereka" (Ibrahim, 1979, p. 217). Tak kalah buruknya, akan muncul dimasa mendatang generasi yang durhaka kepada orangtuanya atau gurunya dan generasi yang selalu menimbulkan permusuhan dengan saudara-saudara mereka sendiri (Ubaid, 1993).

Sikap adil kepada anak-anak adalah perkara yang sangat penting, sehingga Rasulullah Saw., berwasiat dan mengulangnya hingga tiga kali, beliau bersabda:

"Adillah kepada anakmu, adillah kepada anakmu, adillah kepada anakmu!" (Sunan Abu Dawud, Shahih Ibnu Hibban).

Imam Nawawi menomentari hadis ini, bahwa sudah selayaknya untuk disamakan pemberian itu kepada anak-anaknya, dengan cara memberi masing-masing anak sama seperti apa yang diberikan kepada yang lainnya dan tidak boleh dilebihkan, serta disamakan (pemberian) baik anak laki-laki atau perempuan. Dan beberapa pelajaran yang dapat dipetik dari hadis tersebut, yaitu; a) Seorang pendidik baik guru maupun orang tua harus bersikap adil terhadap anak-anaknya dalam segala hal baik dalam hal sikap, pelayanan, dan penilaian. b) Dalam masalah hibah terhadap anak harus dilakukan secara merata dan sama atau tidak semua. Berbeda dengan masalh harta warisan harus merata tetapi tidak harus sama. c) Anak berhak menerima keadilan, tetapi makna keadilan yang sesungguhnya tidak selalu diartikan sama. d) Kesungguhan para sahabat pada ilmu atau hukum Islam ketika menghadapi suatu persoalan selalu bertanya kepada nabi atau dipersaksikan kepadanya.

\subsection{Relevansi Eika Guru Dalam Perspektif al-Tirmidzi Terhadap Profesional- itas Guru Pendidikan Agama Islam}

Berdasarkan uraian di atas, maka relevansi etika guru menurut Abu Isa al-Tirmidzi dalam kitab Sunannya terhadap profesionalitas guru pendidikan agama Islam, yaitu:

Pertama: bahwa di antara etika guru profesional seperti yang ditekankan oleh Abu Isa al-Tirmidzi dalam Sunan-nya adalah keikhlasan.

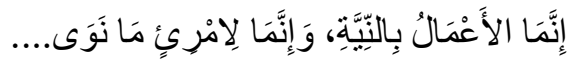

Terjemahan:

"Semua perbuatan tergantung niatnya, dan (balasan) bagi tiap-tiap orang (tergantung) apa yang diniatkan ..."

Riwayat Imam al-Tirmidzi ini menegaskan bahwa seorang guru profesional dalam mengajar senantiasa berniat untuk mencapai keridaan Allah Swt., menyebarkan ilmu, menghidupkan agama Islam, menegakkan kebenaran serta menghancurkan kebatilan. 
Alasan di atas adalah untuk mengembalikan niat awal mengajar adalah sebagai bentuk pengabdian kepada Allah Swt., yaitu dengan merealisasikan misi Rasulullah Saw.. diutus ke muka bumi ini sebagai guru. Dari sinilah urgensi keikhlasan dalam mendidik sangat di butuhkan, sebagai sarana diterimanya amal dan profesi seorang guru.

Undang-undang RI No. 14 Tahun 2005 tentang Guru dan Dosen Bab III Pasal 7 dalam prinsip Profesionalitas menyatakan profesi guru dilaksanakan berdasarkan prinsip memiliki komitmen untuk meningkatkan mutu pendidikan, keimanan, ketakwaan, dan akhlak mulia.

Pasal 20 butir d dalam melaksanakan tugas keprofesionalan, guru berkewajiban menjunjung tinggi peraturan perundang-undangan, hukum, dan kode etik guru, serta nilai-nilai agama dan etika.

Riwayat Abu Isa al-Tirmidzi sangat relevansi terhadap Undang-undang tentang Guru dan Dosan Pasal 7 dan Pasal 20 yakni, kedua-duanya sama-sama menghendaki seorang guru dalam mengajar berlandaskan pada nilai-nilai agama.

Kedua: Guru profesional yang ditegaskan oleh Imam al-Tirmidzi dalam riwayatnya adalah harus memiliki sifat tawādhu' (rendah hati) dan tidak menyombongkan diri.

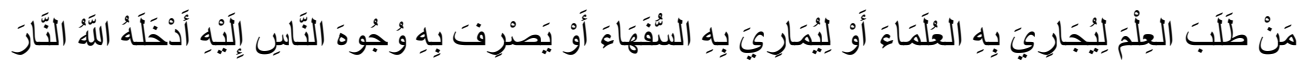

Terjemahan:

"Barangsiapa menuntut ilmu untuk mendebat para ulama, atau untuk mengolokolok orang bodoh atau untuk mengalihkan pandangan manusia kepadanya, niscaya Allah akan memasukkannya ke dalam neraka."

Riwayat Abu Isa al-Tirmidzi ini memiliki relevansi dengan Undang-undang tentang Guru dan Dosen Pasal 20 butir d, dalam melaksanakan tugas keprofesionalan guru berkewajiban menjunjung tinggi peraturan perundang-undangan, hukum, kode etik guru, serta nilai-nilai agama dan etika.

Pasal 10 kompetensi guru sebagaimana dimaksud dalam Pasal 8 meliputi kompetensi pedagogik, kompetensi kepribadian, kompetensi sosial, dan kompetensi profesional yang diperoleh melalui pendidikan profesi.

Kode Etik guru yang mangatur hubungan guru dengan sekolah dan rekan sejawat butir k. Yakni: Guru memiliki beban moral untuk bersama-sama dengan sejawat meningkatkan keefektifan pribadi sebagai guru dalam menjalankan tugas-tugas profesional pendidikan dan pembelajaran.

Riwayat Imam al-Tirmidzi juga memiliki relevansi dengan Undang-undang tentang Guru dan Dosan Pasal 10 dan Pasal 20 butir d, yakni hendaklah seorang guru memiliki kepribadian yang baik dan mampu bersosialisasi dengan baik.

Ketiga: Abu Isa al-Tirmidzi menegaskan bahwa guru profesional adalah transparan dalam menyampaikan ilmunya.

Riwayat Imam al-Tirmidzi menyebutkan:

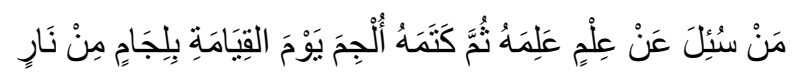

Terjemahan:

"Barangsiapa ditanya tentang suatu ilmu yang dia ketahui kemudian dia menyembunyikannya, maka dia akan dicambuk pada hari kiamat dengan cambukan dari neraka." 
Pasal 10 tentang kompetensi pedagogis, sekurang-kurangnya seorang guru mampu mengembangkan peserta didik untuk mengaktualisasikan berbagai potensi yang dimilikinya.

Riwayat Abu Isa al-Tirmidzi memiliki relevansi dengan Undang-undang tentang Guru dan Dosan Pasal 8 dan Pasal 20 butir a yakni, sama-sama menjelaskan bahwa syarat seorang guru harus berkompeten dalam materi ajarnya.

Undang-undang Guru dan Dosen Pasal 8, Guru wajib memiliki kualifikasi akademik, kompetensi, sertifikat pendidik, sehat jasmani dan rohani, serta memiliki kemampuan untuk mewujudkan tujuan pendidikan Nasional.

Kompetensi guru sebagaimana dimaksud dalam Pasal 8 meliputi kompetensi pedagogik, kompetensi etika, kompetensi sosial, dan kompetensi profesional yang diperoleh melalui pendidikan profesi.

Keempat: Guru profesional yang ditegaskan oleh Abu Isa al-Tirmidzi adalah bersikap adil dan tidak pilih kasih di antara anak didiknya.

Imam al-Tirmidzi meriwayatkan, bahwa Nu'man bin Basyir menceritakan kalau ayahnya pernah memberikan seorang budak kepada anaknya. Lalu ia menemui Nabi Saw, mempersaksikan kepada beliau. Beliaupun bertanya:

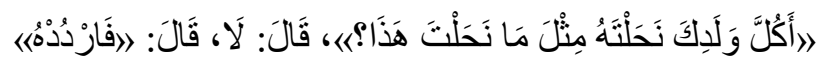

Terjemahan:

“Apakah engkau memberi seluruh anakmu?” ia menjawab; tidak. Beliau mengatakan: "Ambillah ia kembali."

Riwayat Abu Isa al-Tirmidzi ini memiliki relevansi pula dengan Undang-undang tentang Guru dan Dosan Pasal 20 butir c yakni, seorang guru berkewajiban bertindak objektif dan tidak diskriminatif atas dasar pertimbangan jenis kelamin, agama, suku, ras, dan kondisi fisik tertentu, atau latar belakang keluarga, dan status sosial ekonomi peserta didik dalam pembelajaran

Kode Etik Guru Pasal 6 tentang hubungan guru dengan peserta didik: guru berprilaku secara profesional dalam melaksanakan tugas mendidik, mengajar, membimbing, mengarahkan, melatih, menilai, dan mengevaluasi proses dan hasil pembelajaran.

Penulis melihat bahwa sikap adil artinya guru tidak berpihak atau mengutamakan kelompok tertentu. Dalam hal ini, guru harus menyikapi setiap murid sesuai dengan perbuatan dan bakatnya.

Dari pemaparan di atas penulis melihat ada relevansinya terhadap kompetensi kepribadian yaitu beriman dan bertaqwa serta menjadi teladan bagi murid dan masyarakat. Ini berarti bahwa guru harus menjadi model dan panutan bagi seluruh murid. Khususnya dalam proses belajar mengajar dapat mencapai tujuan yang diharapkan dengan cara mengaplikasikan perilaku-perilaku yang luhur, karena hal ini merupakan salah satu kriteria menjadi guru profesional, apalagi guru yang berlabel "Guru Pendidikan Agama Islam."

\section{Kesimpulan}

Berdasarkan hasil penelitian dan analisa yang telah penulis uraikan terdahulu mengenai kedudukan dan etika guru dalam kitab Sunan al-Tirmidzi karya Abu Isa Muhammad bin Isa al-Tirmidzi, maka dapat disimpulkan sebagai berikut: 
1) Seorang guru di berikan kedudukan yang sangat tinggi dalam Islam. di antara kedudukan guru tersebut, adalah guru pewaris Nabi. Karena risalah Rasulullah Saw., ini dilanjutkan oleh para penerus yang mengikuti jejak beliau sampai akhir zaman, mereka adalah para ulama (para guru), karena mereka adalah "ahli waris" risalah Tuhan.

2) Riwayat Abu Isa al-Tirmidzi dalam karyanya Sunan al-Tirmidzi, mengangkat nilai-nilai etika dan moral yang mutlak harus dimiliki oleh guru profesional. Karena segala gerak langkah seorang guru akan dinilai oleh lingkungan, terutama oleh peserta didiknya. Di antara etika yang harus dijaga seperti yang ditekankan oleh Abu Isa Muhammad bin Isa al-Tirmidzi dalam Sunan-nya adalah ikhlas dalam menyampaikan ilmunya, bersifat tawadhu' dan rendah hati, transparan dalam menyampaikan ilmunya dan bersikap adil dan tidak diskriminatif di antara anak didiknya. Etika tersebut sejalan dengan peraturan pemerintah yang tertuang dalam Undang-undang Republik Indonesia No. 14 Tahun. 2005 Tentang Guru dan Dosen. Dalam hal ini, prinsip Profesionalitas menyatakan profesi guru dilaksanakan berdasarkan prinsip memiliki komitmen untuk meningkatkan mutu pendidikan, keimanan, ketakwaan, dan akhlak mulia.

\section{Saran-Saran}

Sekiranya penelitian ini tidak cukup sampai di sini, tetapi berlanjut pada pengembangan yang lebih kompleks, karena penulis menyadari bahwa penulisan ini jauh dari kesempurnaan. Karena itu penulis mengajukan saran-saran dan masukan yang dianggap perlu untuk pengembangan lebih lanjut:

- Untuk menghasilkan pemahaman hadis yang lebih sempurna dan pesan moral yang lebih mendalam lagi, maka perlu menggunakan pendekatan-pendektan lain secara optimal.

- Perlu kajian kembali atas hadis-hadis yang berkaitan dengan tema di atas sehingga jangkauannya menyeluruh dan kompleks.

\section{Daftar Pustaka}

'Ulwan, A. N. (2008). Tarbiyah al-Aulad fi al-Islam. Cairo: Dar al-Salaam. Abdullah, Y. (2006). Pengantar Studi Etika. Jakarta: PT Raja Grafindo Persada.

Abu Ibrahim Muhammad Ali. (2016). Bersikap Adil Terhadap Anak. Retrieved May 23, 2016, from https://maktabahabiyahya.wordpress.com/2013/02/27/bersikap-adil-terhadapanak/

Abu Salim, D. M. S. (2006). Manâhij al-Muhaddsîn min al-Qarn al Tsâlis al Hijri hatta 'Asrinâ al Hâdhir. Cairo: Jâmi'ah al-Azhar.

Al-Asqalany, A. al-F. A. bin A. bin H. (n.d.). Fath al-Bari Syarh Shahih alBukhari. Beirut: Daar al-Fikr.

Al-Baihaqi, A. B. A. bin al-H. (2003). Syu'ab al-Iman. Riyadh: n.p.

Al-Bantani, M. N. bin U. al-J. (1439). Bahjat al-Wasaail bi Syarh al-Masaail. Mesir: Musthafa al-Babi al-Halabi.

Al-Darimi, A. H. M. bin H. bin A. (1973). Al-Tsiqat. Haedar Abad: Dairah alMa'arif al-'Utsmaniyah.

Al-Dzahabi, A. A. S. al-D. M. bin A. (1998). Tadzikarah al-Huffazh. Beirut.

Al-Dzahabi, S. al-D. (1985). Siyar A 'lām Nubalā'. Beirut: Daar al-Fikr.

Al-Ghazali, A. H. M. bin M. (2005). Ihyâ 'Ulum al-Din. Beirut. 
Al-Jawziyyah, A. A. M. bin A. B. I. Q. (1423). I'lām al-Muwaqi'īn 'an Rabb al"Ālamin, Takhrij: Abu Umar Ahmad Abdullah. Cairo: Daar al-Jauzi.

Al-Khatib, M. A. (1989). Ushul al-Hadits: Ulumuhu wa Musthalahahuh.

Al-Math, M. F. (1995). Min Mu'jizaat al-Islam. Jakarta: Gema Insani Press.

Al-Mizzi, A. al-H. J. (1980). Tahdzib al-Kamal fi al-Asma al-Rijal. Beirut: Muassasah al-Risaalah.

Al-Mubarakfury, A.-I. al-H. M. A. al-R. (1990). Tuhfah al-Ahwadzy bi Syarh Jami' al-Tarmidzi. Beirut.

Al-Munawi, M. A. al-R. (n.d.). Faidh al-Qadir, Juz 7. n.c: n.p.

Al-Nahlāwi, A. (2007). Ushūl al-Tarbiyah al-Islāmiyah wa Asālibuhā fì al-Baiti wa al-Madrasah wa al-Mujtama. Beirut.

Al-Nawawi, A. Z. M. al-D. Y. bin S. (1998). Al-Minhaj Syarh Sahih Muslim bin al-Hajjaj. Beirut: Daar al-Fikr.

Al-Sabt, K. bin U. (2016). A'mal al-Qulub.

Al-Syaqawi, S. A. bin A. (2013). Tawạ̣̄hu' al-Nabi Alahi al-Shalat wa alSalaam.

Al-Tabba', I. K. (2001). al-Imam al-Tirmidzi al-Hafiz al-Naqid Faqih al-Salaf wa Jami' al-Sunan. Damaskus.

Al-Tuwanisi, A. F. (1994). Perbandingan Pendidikan Islam. In Perbandingan Pendidikan Islam (pp. 76-110).

Arberry. (1996). Sufism: An Account of the Mystics Of Islam. London: George Allen \& Unwin Ltd.

Awwad, J. M. (1996). Mendidik Anak Secara Islam. Jakarta: Gema Insani Press.

Azami, M. M. (1996). Metodologi Kritik Hadis. Bandung: Pustaka Hidayah.

Blog Ahlulhadist. (2007). Jumlah Hadis Sunan Abu Daud, Nasai, Al-Tirmidzi, Ibnu Majah. Retrieved July 10, 2016, from https://ahlulhadist.wordpress.com/2007/10/16/jumlah-hadist-4-sunan-abudawud-nasai-timidzi-ibnu-majah

Echsanudin. (2011). Etika Guru menurut Ibn Jamā'ah dan Relevansinya dengan Kompetensi Guru.

Fahmi, A. H. (1979). Sejarah dan Filsafat Pendidikan Islam. Bandung.

Faturahman, O. (2012). Ithaf al-Dhaki Tafsir Wahdat al-Wujud Bagi Muslim Nusantara. Jakarta.

Hamid, S. bin A. (1999). Manâhij al-Muhaddisîn. Riyadh: Dar Ulum al-Sunah.

Ibrahim, I. A. (1979). Tahqiq al-Qadhiyah fi al-Farq Baina al-Risywah wa alHadiyah. Univ al-Malik Abd al-Aziz.

Jamil, S. (2013). Guru Profesional. Yogyakarta.

Khon, A. M. (n.d.). Hadits Tarbawi, Hadits-Hadits Pendidikan. n.c.

Masyhur, K. (1994). Membina Moral dan Akhlak. Jakarta: n.p.

Mulyasa, E. (2008a). Menjadi Guru Profesional Menciptakan Pembelajaran Kreatif dan Menyenangkan. Bandung: Remaja Rosdakarya.

Mulyasa, E. (2008b). Standar Kompetensi dan Sertifikat Guru. Bandung: Remaja Rosdakarya.

Munawir, \& Al-Bisri. (1999). Kamus Al-Bisri. Surabaya: Pustaka Proressif.

Munawwir, A. W. (2007). Al-Munawwir Kamus Indonesia-Arab. Surabaya.

Nada, A. 'Aziz bin F. al-S. (2005). Mausu'ah al-Adab al-Islamiyyah alMurattabah 'ala al-Huruf al-Hijaiyyah. Jakarta: Maghfirah Pustaka.

Nafis, M. M. (2011). Ilmu Pendidikan Islam. Yogyakarta: Teras. 
Nizar, S. dan R. (2005). Ensiklopedi Tokoh Pendidikan Islam. Jakarta: Quantum Teaching.

Poerwadarminta, W. J. . (2011). Kamus Umum Bahasa Indonesia. Jakarta: Balai Pustaka.

Rahmadi. (2001). Guru dan Murid dalam Perspektif al-Mawardi dan al-Gazali. Banjarmasin: n.p.

Rahmaniyah, I. (2010). Pendidikan Etika Konsep Jiwa dan Etika Prespektif Ibnu Maskawaih. Malang.

Sudiyono, M. (2009). Ilmu Pendidikan Islam. Jakarta: Rineka Cipta.

Supriyadi. (2010). Etika dan Tanggung Jawab Profesi Hukum di Indonesia. Jakarta: Sinar Grafika.

Sutarmadi, A. (1998). al-Imam al-Tirmidzi: Peranannya dalam Pengembangan Hadis dan Fiqih.

Suwaid, M. I. A. al-H. (2009). Manhaj Tarbiyah Nabawiyah lith-Thifli. n.c: n.p.

Suyitno. (2006). Tokoh-tokoh Pendidikan Dunia.

Syekh, S. A. al-‘Aziz A. (2006). Thalib al-Ilmu wa al-Bahts. Riyadh: Maktabah al-Syamilah.

Tafsir, A. (2010). Ilmu Pendidikan dalam Perspektif Islam. Bandung.

Taimiyah, I. (n.d.). Majmu' al-Fatâwâ. n.c: n.p.

Taimiyah, T. al-D. A. bin A. al-H. bin. (1987). al-Fatāwā al-Kubra, Beirut: Dar al-Kutub al-Ilmiyah. Beirut: Daar al-Kutub al-Ilmiah.

Ubaid, M. al-R. (1993). Huquq al-Abna' "ala al-Aba." Cairo: Maktabah al-Turats al-Islami.

Unger, H. G. (2013). Enciclopedia of America Education. New York: Islam House.

Yunus, M. (n.d.). Kamus Bahasa Arab-Indonesia. Jakarta.[] 